\title{
Designing Responsibility: The Problem of Many Hands in Complex Organizations
}

\section{Citation}

Thompson, Dennis F. 2017. "Designing Responsibility: The Problem of Many Hands in Complex Organizations." In The Design Turn in Applied Ethics, eds. Jeroen van den Hoven, Seumas Miller, and Thomas Pogge, 32-56. Oxford: Oxford University Press

\section{Permanent link}

http://nrs.harvard.edu/urn-3:HUL.InstRepos:37092148

\section{Terms of Use}

This article was downloaded from Harvard University's DASH repository, and is made available under the terms and conditions applicable to Open Access Policy Articles, as set forth at http:// nrs.harvard.edu/urn-3:HUL.InstRepos:dash.current.terms-of-use\#OAP

\section{Share Your Story}

The Harvard community has made this article openly available.

Please share how this access benefits you. Submit a story.

Accessibility 


\title{
Designing Responsibility: The Problem of Many Hands in Complex Organizations*
}

\author{
Dennis F. Thompson
}

Forthcoming in Designing Ethics, eds., Jeroen van den Hoven, Seumas Miller and Thomas Pogge, Cambridge University Press, 2017

When terrorists attack, oil spills, banks fail and other "stuff happens,", we naturally look for individuals to blame. But in modern society the most serious damage is usually done by large organizations. Because many different individuals in an organization contribute in many different ways to the decisions and policies, it is difficult even in principle to identify who is responsible for the results. The profusion of agents obscures the location of agency This is what is known as the problem of many hands. ${ }^{2}$

The problem poses a challenge to the general approaches to assigning responsibility. If we try to hold individuals responsible (the individualist approach), individuals who could not have prevented the outcome are either unfairly sanctioned or they are allowed to "take responsibility" without suffering any consequences. ${ }^{3}$ But if we hold only organizations responsible (the collectivist approach), then either all members are equally blameworthy or all are excused, regardless of the degree of their responsibility. On both approaches, we violate standard ideas of moral responsibility either by targeting individuals who are not responsible, or by exonerating individuals who may be at least partly responsible. The result is not only unfair to the individuals (and sometimes the organizations as well), but it also undermines the set of incentives on which the organization and society depend to encourage responsible action. If the incentives are not directed toward actions or omissions for which individuals and organizations could reasonably believe they are morally responsible, the incentives and therefore the means of accountability are less likely to be effective.

The collectivist approach has been more prominent the philosophical literature (Smiley, 2011; French, 2006; May \&

Hoffman, 1991). ${ }^{4}$ It is claimed to have two principal advantages: if we target only the organization, we have identified an agent that we can hold responsible without unfairly blaming individuals; and also the agent that has the 
greatest capacity to provide compensation and undertake reforms. This approach has been assumed to require showing that an organization can be a moral agent. The assumption has led to a spate of intricate discussions about whether collectivities can be moral agents in the relevant sense. (Smiley, 2011) While philosophically interesting, the practical implications of any answer to this question are not clear. If organizations are not considered moral agents, there is still no reason that they cannot be fined or their behavior condemned. ${ }^{5}$ Compensation and deterrence can be no less effective. Even if collectivities are regarded as moral agents just like persons (and what that means still seems obscure), it is still the individual members of the organizations who suffer the consequences that follow from the ascription of responsibility, and individual officials who will have to respond. Thus even on this approach we cannot completely avoid dealing with individual responsibility. ${ }^{6}$ We do not have to reject the possibility of holding organizations themselves responsible in some way, and certainly should not rule out subjecting them to legal or financial sanctions. Some such responsibility, with or without moral agency, is necessary and appropriate in modern society. It is the "only" that is objectionable. We still need to find a role for individual responsibility.

\section{Individual Responsibility}

The individualist approach is more robust in organizational settings than usually assumed. ${ }^{7}$ The standard criteria of moral responsibility can be applied even in many hands circumstances if we do not allow familiar excuses to undermine them. On the standard view, an individual is morally responsible for an outcome insofar as an individual is morally responsible for an outcome insofar as (1) the individual's actions or omissions are a cause of the outcome; and (2) the actions or omissions are not done in ignorance or under compulsion. ${ }^{8}$ The first refers to causal responsibility, and the second, to volitional responsibility.

The standard formulation of the causal criterion stipulates that an individual is a cause of the outcome if it would not have happened but for the individual's act or omission. ${ }^{9}$ In applying the criterion to organizations, however, we have to qualify it in two ways. First, to assert that an individual is a cause on this criterion only empirically connects his or her action with the outcome - along with the actions of many other hands and the influence of many other forces. It does not establish that the individual is the most important cause, even less that the individual is morally responsible for the entire outcome. The individual is only a causal factor, one of "a plurality of distinguishable causal conditions," as distinct from a causal citation, "a judgment that cites one of the numerous eligible causal 
conditions as 'the cause' [or a significant cause]" (Feinberg, 1970, pp. 201-202). If we wish to select one individual from among all the other causal factors in the chain of causation, we have to invoke other considerations, many of which involve a judgment about whether the action is one that we empirically or normatively expect in these circumstances (Feinberg, 1970, pp. 201-205). For example, an oil company executive's failures may have contributed less to the disaster than the actions of the managers and workers on the rig, but if his failures are a dereliction of duty he may be legitimately cited as one of the most important causes.

Second, under some conditions an individual can be held responsible even if an outcome would have happened no matter what that individual did or failed to do. Otherwise, in many hands cases, everyone might escape responsibility. Consider what may be called the excuse from alternative cause: "If I hadn't done it, someone else would have," or "If I don't do it, someone else will." The excuse is more common in official than in personal life because in organizations the empirical assumption on which it depends is more likely to be true; in organizations persons often are fungible. But if the excuse is accepted for one, it may have to be accepted for all. To relieve one person of responsibility, the excuse asserts that other people (the alternative causal agents) would be responsible for the action; but if the excuse is valid, each of the other people would be exonerated, seriatim, in the same way as the first person. In other words, if the excuse is valid, no one is responsible.

Therefore the causal criterion is usually modified so that it covers cases in which the outcome is overdetermined. It should be understood to allow an individual's action to qualify as a cause if the action would have been necessary to produce the outcome, had no other action sufficient to produce the outcome been present (Hart \& Honoré, 1959, p. 117). ${ }^{10}$ Other cases turn on how the outcome itself is described. If we characterize the outcome in very general terms — say, the environmental harm from the Gulf oil spill—we may not be able to identify any individual as a cause on a strict criterion. But if we describe the outcome more specifically-the failure to take usual safety precautions in drilling the well—we may have more success in locating responsible individuals. Ascribing moral responsibility calls for specificity in characterizing outcomes as much as in identifying agents. We have to try to be as precise about what individuals are responsible for, as about who the individuals are. Furthermore, such specificity should include responsibility for patterns of decisions and decision making. The outcomes for which we hold officials responsible, as will become clear, can include the continuing practices and structures of an organization. 
The second criterion — volitional responsibility—stipulates in its most general form that individuals are responsible for an action insofar as they could have done otherwise. ${ }^{11}$ Unlike the causal criterion, which only sets a threshold for responsibility, the volitional criterion can also determine degrees of responsibility. Inability to act otherwise takes many different forms, ranging from general incapacity (such as insanity) to specific defects in particular actions (such as inadvertence). Most relevant for assessing the actions of organizational officials are these specific faults, which may be considered under the traditional Aristotelian categories of ignorance and compulsion (Aristotle, 1963, Bk. III.1; cf. Glover, 1970, esp. 60-61; Donagan, 1977, pp. 112-142).

Ignorance of what one does (not knowing that a certain description applies to one's action) counts as an excuse only if the ignorance is not deliberate (as in cases of deniability) or not negligent (as in cases of dereliction). In large organizations, the standards of negligence should depend in part on moral and political considerations, such as the societal importance of the outcomes in question, and the efficacy of deterrence in the circumstances (Thompson, 1987, pp. 71-75). To reject a plea of ignorance, we do not have to show that an executive should have foreseen the specific act of particular subordinates (for example, that the drilling team would neglect to follow certain procedures). It is sufficient that the executive should have known that mistakes of the kind that occurred were probable (for example, when there are strong incentives to complete the job as fast as possible, the risk that safety may be compromised increases). In organizations, certain patterns of fault are common enough that we should expect any competent official to anticipate them and to take reasonable precautions to avoid them or at least to minimize their harmful consequences.

The compulsion that officials cite to excuse their conduct is rarely the extreme physical and psychological kind that philosophers and lawyers usually discuss. When officials proclaim "I had no choice," we should not take them literally. They can usually be understood as implying that they did not choose the range of alternatives within which they made some decision. Like Aristotle's sea captain, an official confronts two undesirable options- - jettisoning the cargo or sinking the ship (Aristotle, 1963, Bk. III.1,line. 1110a). The duties of office conspire with the forces of nature to pose a choice between disagreeable alternatives. Limitations on the range of alternatives do not eliminate an official's responsibility, they only mean that we must specify, in any ascription of praise or blame, what alternatives were realistically available. Perhaps the government regulators had to allow the oil companies to take 
the greater risks created by deep water drilling, but they had the authority to insist that the companies also invest more in safety to an extent commensurate with those risks.

If we are careful in interpreting and applying the criteria, we can identify individuals who are responsible for many of the decisions that lead to organizational disasters, or at least partly responsible. We can reject many of the excuses that are used to avoid individual responsibility (Thompson, 1980; Thompson, 2005; Luban et al., 1992). We can and should carry the pursuit of individual responsibility much further than is usually assumed to be possible in theory, or usually attempted in practice. Even so in many cases the problem of many hands persists, because even if the individuals who made mistakes and contributed to the outcome can be identified, the consequences of their acts (as well as their omissions) are often greatly disproportionate to the harms brought about by the organization. The harmful effects of the oil spills, the financial crisis, or terrorist attacks go beyond anything that any individual may have done or could be reasonably held responsible for. Although there were individuals who clearly made mistakes and directly caused the harm, they were no more — and sometimes less - culpable than others higher in the hierarchy. Yet even the errors of those higher level officials, considered one at a time, pale in comparison with the damage done by the organization or organizations. Once we apportion blame and apply sanctions to every one as far as possible, we would still find that the enormity of the outcome exceeds even the collective sum of the actions of individuals. It seems that full responsibility for the collective harm is hard to pin on any set of individuals in these cases no matter how many hands we manage to locate.

The individualist approach thus reaches a limit in trying to attribute responsibility for harms brought about by organizations. But so does the collectivist approach because, as already noted, it cannot escape relying to some extent on individual responsibility in imposing sanctions and carrying out reforms. Once we have reached this limit and exhausted the supply of individual responsibility for an organizational failure, is there nothing more to be said or done about responsibility? Must we throw up our hands in face of the problem of many hands? If so, we are at risk of accepting what one political scientist concluded about bureaucratic inefficiency: "We may accuse [public officials and organizational executives] because, intuitively, we want to divert the guilt from the real cause: ourselves. No one element of the population is responsible...we all have a hand in it" (Kaufman, 1977, pp. 27-28). If everyone is responsible, no one is likely to do anything about it, whatever $i t$ is. That is not a promising approach for making either individuals or organizations more responsible. 


\section{Design Responsibility}

We can still find a role for individual responsibility if we shift our perspective from the responsibility for outcomes to the responsibility for the design of organizations. The source of many of the organizational disasters in recent years can be found in the structure of the organization and its relationship to other organizations. The defective structures and relationships may or may not be inherent in the design, but once their harmful effects can be observed, they can be changed. When those who have the knowledge and power to make the changes fail to do so, they may be held responsible for the harms that result, even large-scale harms. Certainly, when officials who had the authority and knowledge to make changes in an organization failed to do so, they are rightly held responsible. Part of any review of responsibility should therefore examine who designed or failed to redesign the flawed processes that could foreseeably lead to harmful outcomes.

But as we go looking for the individual designers, we will confront the problem of many hands again. The organizational design is often the product of many decisions (as well many non-decisions) by many different people over a long period of time. Some of the designers are no longer around. Potential designers who knew about the defects may not have had the power to fix them, and those who had the power may not have known (though usually they should have known). If we look only for design faults in the past, we are likely again to find too many hands with too little responsibility.

Therefore in shifting to design responsibility we also need to adopt a forward-looking conception of responsibilitywhat may be called prospective design responsibility. We examine past failures - but chiefly for the purpose of preventing future ones. In carrying out such an examination, we first need to locate, as far as possible, not only the structural defects in the organization but also the individual actions that may have contributed to the failure. That is necessary so that we can separate the structural defects from the individual errors. Then prospectively, we designate specific individuals or groups of individuals as overseers, who can be held accountable for monitoring the structure of the organization and making or recommending changes in it as necessary. In the future, if they fail to fulfill that responsibility, we will know whom to blame, even if the organizational disaster itself is the result of the actions of many hands. 
The body charged with design responsibility should be independent and knowledgeable. Each of these requirements tracks one of the criteria of volitional responsibility. A body is independent insofar as it is not subject to undue pressure (not acting under compulsion). Financial dependence is the most obvious way this principle can be violated. If the officials in the government agency regulating the oil companies are looking for jobs in the industry, they are less likely to make independent judgments. Other pressures can have similar effects-for example, the legitimate goal of increasing energy supplies can conflict with the responsibility of ensuring safe drilling practices. The second requirement (not acting in ignorance). refers to the knowledge that responsible agents should have Overseers cannot monitor and redesign an organization unless they know a lot about it. For effective oversight they need to know not only about specific misdeeds, but patterns and tendencies, which may not yet have caused problems but are likely to do so in the future. This kind of knowledge, often specific to the organization, comes largely from experience within the organization. It is more likely to come to overseers who over the years have developed friendships with colleagues who give them insider information. In this way, the knowledge principle may conflict with the independence principle. Knowing more may require depending more. One of the challenges of design responsibility is how to reconcile this tension (Thompson, 2005, pp. 256-59).

The shift to prospective design responsibility can preserve a role for individual responsibility in many hands circumstances that would otherwise frustrate attempts to assign it. However, overcoming the many hands problem in this way requires more than merely adding design responsibility to the job descriptions of existing officers and members of the organization. It requires establishing new offices or institutions with individuals specifically charged with overseeing organizational changes to correct structural deficiencies that could result in disastrous failures. Ironically, it requires creating more hands — but with more precisely defined responsibilities.

How design responsibility might work can be shown by examining its application in three different cases of major organizational failure. (The accounts to be given are of course selective, and should be regarded as illustrative sketches rather than conclusive assessments.) In each case an official body was appointed to investigate the failure, and some of these bodies came closer than others to following the approach proposed here. The bodies charged with redesigning responsibility themselves may be more or less responsible in the sense that they are more or less independent and knowledgeable. 


\section{Unprevented Terror}

After the terrorist attack that destroyed New York's Word Trade Center and part of the Pentagon, and killed nearly 3,000 innocent people on September 11, 2001, the pressure grew to investigate why the attack had not been prevented, and how to guard against the risk of another in the future. Congress created a 10-member bipartisan commission to carry out this task. It interviewed hundreds of individuals, reviewed thousands of documents, some top secret, and prepared dozens of staff reports. The Commission's 567-page final report, issued in July 2004, presented a riveting narrative of the policies and events leading up to the attack, detailed descriptions of the government's response, and a set of recommendations for changes in the practices and organization of the FBI, CIA, NSA, FAA, and Congress itself, among other institutions (National Commission on Terrorist Attacks, 2004). The initial reaction to the Report was highly favorable. Remarkably well written and replete with new information, the document was turned into a book and immediately became a best seller.

But on closer reading, many found the report deficient. The critics included not only the families of the 9/11 victims, but a former aide in the Bush White House and a senior adviser to the Commission (Falkenrath, 2004; May et al., 2005; May, 2007, pp. 19-25; and Shenon, 2008, pp. 99-100, pp. 102-03). The most salient criticism they raised is directly relevant to the problem of responsibility. The report failed to hold any individual accountable; it declined to pass judgment on individuals who made the key decisions. The Commission adopted a "no fault" theory of government - “an imprecise, anodyne and impersonal assignment of responsibility for the U.S. government's failure to prevent the 9/11 attacks" (May et al. [Falkenrath], 2005, p. 211).

The Commission's decision to avoid singling out individuals was deliberate: "Our aim has not been to assign individual blame. Our aim has been to provide the fullest possible account of the events surrounding $9 / 11$ and to identify lessons learned" (National Commission on Terrorist Attacks 2004, p. xvi). The justification implied in the second sentence is puzzling. Providing a full account and identifying lessons would seem to be a reason to try to assign rather than to ignore individual responsibility. Later one of the co-chairs gave the more likely reason: “...if we had come up with a list of bad actors, it would have blown the commission apart and it would have blown any credibility we had. ...If we had a paragraph saying Condi Rice really screwed up, that's all the New York Times would have written about... That level of personal accountability would have been a total dead end — there's no end to it" (Shenon, 2008, p. 405). 
Although the Commissioners were commendably conscientious and public spirited, the Commission was, in origin, composition and foreseeable reception, a political body, and its scope for action was inevitably shaped by political considerations. It was less independent in that respect than a less political body would have been. The understandable political calculation the co-chairs made had serious costs. First, an analysis that neglects individual responsibility is an inadequate guide for decision makers in the future. Refusing to "name names" is "exactly the wrong message to send to future government officials and the people who train them" (May et al. [Falkenrath], 2005, p. 211) More generally, for the purposes of redesigning incentives for responsibility in the future, we need to know which were effective under what circumstances in the past.

Second, avoiding discussion of individual responsibility weakened the recommendations for institutional reform. The Commission's recommendations for change were only loosely connected to its analysis of the failures. That analysis relied on very general, impersonal concepts such as a "failure of imagination," the most prominent of the four major "failures" it cited (National Commission on Terrorist Attacks, 2004, p. 339-47). Presumably everyone should be more imaginative. Analyzing the "management failure," the Report retreats to the passive voice: "Information was not shared...analysis was not pooled. Effective operations were not launched..." (National Commission on Terrorist Attacks, 2004, 353). Responsibility designers would look in vain for the agents who failed to share information, pool the analysis, or launch the operations. They would be at a loss to know which roles or offices should be redesigned to prevent these failures in the future. While the diagnosis generally avoided singling out individuals, the prescriptions did not. Many of the recommendations called for changes that would assign definite responsibilities to specific individuals, such as the proposal for a new National Intelligence Director (National Commission on Terrorist Attacks, 2004, 339). The connection between the diagnosis and the prescription remained obscure.

The families of the victims demanded that names be named ("the Commission should point fingers") because they wanted officials to be fired or disciplined or at least shamed. (Shenon, 2008, pp. 99-100, pp. 102-103). They had a point, but it is not the same point that should concern responsibility designers. To reform structures, we have to know what roles or offices should be changed and in what ways. That does not mean that we have to name names, but it does mean that we need to know which individuals made which decisions. Otherwise, it would not be possible to tell how much is determined by individuals and how much by the structures. 
Bush's counterterrorism adviser Richard Clarke charged that National Security Adviser Condi Rice (and others) failed to take the terrorist threat seriously (Shenon, 2008, pp. 280-89). In the Clinton administration Clarke's office gave him more regular and direct access to the President and other principals than it did in the Bush administration, which (in Clarke's view) downgraded the office. Was this dereliction on the part of Rice and others, or was it the result of an organizational defect that should be corrected? Similarly, in the case of many of the other specific failures described in the report—-for example, no use of force against the terrorist training camps in Afghanistan, no hardening of cockpit doors on civilian aircraft, no watch-listing of suspected terrorists-it would be essential to know why those who could have acted (presumably a small and identifiable number of individuals) failed to do so.

Close reading of the Report reveals the identity or at least the position of many of those who had the knowledge and the power to act, not necessarily to prevent the attacks but to reduce the chances by correcting or bypassing deficiencies in the organization. The senior officials in the Washington office of the FBI for example ignored repeated warnings from their field officers (National Commission on Terrorist Attacks, 2004, pp. 273-176). The Report mentions an earlier effort to make institutional changes that might have helped avoid such problems, but blames departments (Justice and Transportation), not individuals for this design failure (National Commission on Terrorist Attacks, 2004, p. 352). ${ }^{12}$

Even if we do not want to discipline individuals, and indeed if we believe that some should be excused because of structural defects over which they had no control, we cannot redesign the roles or offices in which they acted without knowing what decisions which individuals took or failed to take, and what realistic alternatives they might have had.

It may be difficult and perhaps practically impossible to criticize how the roles or offices were performed without in effect revealing the identity of the persons who hold them. But for the purposes of organizational design, we need to know who did what, not to ascribe blame or mete out punishment, but to guide the design of the roles and structures to prevent future failures including failures of responsibility. The former Bush aide's critical summary indicates why the report could not be such a guide. 
Even if authority is widely and confusingly spread around the executive branch, ... the starting point in any after-the-fact governmental analysis should always be the concept of personal responsibility. 9/11 commission instead focused on a handful of amorphous, impersonal causal factors, none of which is nearly as compelling as the notion that an identifiable set of government officials made bad decisions about where to apply their energies and, as a result, failed to do the job that the American people had the right to expect them to do (May et al. [Falkenrath], 2005, p. 211).

The experience of the Commission suggests several lessons for designing responsibility. First, if a post mortem on a major organizational disaster such as $9 / 11$ is expected to produce recommendations for organizational change, a bipartisan commission or other political body is probably not the best instrument. In this case, the supposed advantage of influencing Congress did not materialize. Many of the recommendations were ignored, and others watered down. Significantly, the National Intelligence Director, who was now to have personal responsibility for coordination and management, never received the budgetary and personnel authority to do the job. A commission may be appropriate, but it should not be so closely connected to the political parties, and should include experts and citizens rather than partisan political figures.

Second, an essential aim of any attempt to redesign responsibility in an organization after a disaster should be to pursue individual responsibility as far as possible. The critiques of the $9 / 11$ commission make clear that the possibilities for locating individuals who failed as well as those who succeeded in fulfilling their responsibilities are greater than is usually assumed, even in a massive large scale disaster of this kind. We do not have to hold them responsible for the whole disaster in order to hold them responsible for specific and substantial mistakes. Also, the widely shared belief that the disaster would have occurred no matter what any particular individual had done or failed to do does not necessarily excuse anyone. That is just a variation of the excuse from alternative cause which we have seen is not usually valid. Nor does the fact that the individual failures do not match the enormity of the disaster preclude assigning responsibility for more specific mistakes. Many individuals should and could have acted otherwise, and their mistakes contributed in various ways to specific and limited failures in the chain of events that led to the larger disaster. Distinguishing the structural from the individual sources of these mistakes is necessary for 
the task of designing responsibility. The assignment of individual responsibility is thus the handmaiden to the prevention of collective disaster

Finally, part of the redesign of any organization should involve specifying more clearly which individuals should be responsible for which decisions, and giving them the independence and information to fulfill their responsibilities. Some of the Commission's recommendations moved in that direction, but their more comprehensive efforts were weakened by their own analysis, which more readily suggested impersonal remedies such as the implication that everyone should be more imaginative or that Congress should be better organized. Who exactly should take responsibility for bringing about these changes? The Commission suggested some specific reforms but was too often silent about who should be responsible for carrying them out (e.g. National Commission on Terrorist Attacks, 2004, pp. 419-421).

\section{Spilt Oil}

In April 2010 in the Gulf of Mexico, a deep water oil drilling rig operated by British Petroleum exploded, killing 11 workers and causing a massive gusher that eventually released nearly five million barrels of crude oil into the Gulf.

The spill caused extensive and continuing damage to marine and wildlife habits and to the fishing and tourist industries on which many of the residents of the Gulf depend. The government held BP responsible for managing the clean up and compensating victims, but the various investigations and legal proceedings have still not entirely settled which of the several companies and individuals involved are responsible for the spill and its effects.

In May 2010, President Obama appointed a seven-member National Commission to investigate the spill with the aim of "providing recommendations on how we can prevent - and mitigate the impact of - any future spills that result from offshore drilling" (White House Press Office, 2010). Although the Commission was called "bipartisan" because the co-chairs were identified as a Democrat and a Republican, the composition and the mission were not political in the way that the 9/11 Commission was. Both the co-chairs had held positions and experience directly relevant to environmental disasters of this kind. The other members were recognized independent experts, mostly researchers or leaders of apolitical institutions. The Commission had both independence and knowledge.

Even though its explicit charge was forward-looking, the Commission realized that it had to examine the causes, and that would require giving some attention to decisions that individuals had made. The commission "did not try to 
assign specific blame for a catalog of mistakes and shortcuts taken by the companies and their employees, but it is clear from the report that the major agents engaged in highly risky behavior that neither senior management nor government regulators properly oversaw" (Broder, 2011). The Commission concluded that "the immediate causes of the Macondo well blowout can be traced to a series of identifiable mistakes made by BP, Halliburton, and Transocean that reveal such systematic failures in risk management that they place in doubt the safety culture of the entire industry" (National Commission, 2011, p. vii). Among the mistakes: engineers received approval from managers to use riskier pipes and casings than company's own standards required, the cementing procedure done by Haliburton was known to be flawed, supervisors ignored early warnings that key pieces of equipment such as the blow out preventer might fail, TransOcean (the operator of the rig) skipped the certification procedure that might have caught the flaws, preparations and technology for coping with a spill of this kind were completely inadequate (the "spill response plan" included measures to protect walruses, seals and sea lions), the workers did not know at the time of the explosion who was in charge on the rig, and the early responses by the companies and the government were delayed and marred by misinformation.

Many individuals had both the authority and knowledge to change the practices that led to many of these errors, but the pressure to save time and money evidently drove the decision making more than concern for safety (National Commission, 2011, pp. 125-126). According to the Commission, "decisionmaking processes at Macondo did not adequately ensure that personnel fully considered the risks created by time- and money-saving decisions. Whether purposeful or not, many of the decisions that BP, Halliburton, and Transocean made that increased the risk of the Macondo blowout clearly saved those companies significant time and money" (National Commission, 2011, pp. 125-126).

Eventually the numerous legal proceedings underway began to identify some individuals who were more responsible than others, and allocate some responsibility among the three corporations involved. But undoubtedly even the cumulative total of legal liability will not be commensurate with the damage caused by the spill. The more constructive effort now focuses on assigning responsibility for preventing or reducing the risk of similar disasters in the future, and the first line of response here is government oversight. The oil spill provides instructive lessons here. First, there were several different agencies responsible for oversight, and none had overall authority. The responsibility design was diffuse, which probably contributed to the disaster. Second, the principal agency for 
regulating the drilling, the Mines Minerals Service (MMS), granted so many exceptions and overlooked so many violations that its officials may be as much responsible for the disaster as many of those at BP (Urbina, 2010). Without identifying the specific culprits, the Commission made clear that agency officials had missed many opportunities for redesigning the regulatory system: "The agency's efforts to adopt a more rigorous and effective risk-based safety regulatory regime were repeatedly revisited, refined, delayed, and blocked alternatively by industry or skeptical agency political appointees" (National Commission, 2011, p. 71).

To some extent the MMS failures were the result of manifest corruption: the top officials had cozy relationships with the industry they were supposed to regulate, and enjoyed many perks while in office and employment opportunities when they left. But the failures were also the result of a responsibility design problem. The agency was charged with two different and conflicting tasks: promoting the industry (encouraging drilling), and regulating it (ensuring that safety was the highest priority). Even without the corruption, the promotional efforts would have been likely to overshadow the regulatory responsibilities. The implication is that organizational designers should divide conflicting responsibilities by assigning different agencies the different tasks when they could conflict. That is in fact one of the steps that the government has finally taken in this case, splitting the previous agency into three different parts to avoid the conflicts (U.S. Secretary of the Interior, 2010).

But the problem persists because the individuals who know the most about the industry and how to regulate it effectively, come from the same backgrounds, and often move in the same circles as the people they are regulating. Even if they are not looking for opportunities in industry, they are more likely to see the world from the perspective of those whom they are regulating than from the perspective of the citizens who may be harmed by mistakes that the industry (or the regulators) make. To the extent that government seeks the most competent experts to conduct oversight, this design problem cannot be avoided at this level.

Another lesson, then, is that to address this kind of problem, we need an additional body to ensure that some oversight responsibility is assigned to people who have a different perspective. We need a body composed of members who would give more weight to the effects on citizens, and who are more willing to challenge expert opinion. One method that has been tried in similar circumstances is a citizens' advisory council (Applegate, 1998)Such a body was set up after the Alaskan Valdez disaster, but legislation to require that it be established in other regions failed to pass in Congress. The National Commission (2011) briefly reintroduced the proposal: any 
new "structure should therefore include a citizens' advisory council to provide formal advice and a direct line to citizens' concerns" (p. 212).

Thus, two of the lessons of this episode_-divide conflicting tasks, and add checking authorities - in effect point to responsibility reforms that would (ironically) address the problem of many hands by multiplying the hands. That solution might seem to recreate the problem it is supposed to solve. But the multiplication is not the same. The difference is that the hands would be specifically charged with oversight and nothing else, and they would be independent in the sense that neither their mission nor their interest would conflict with their responsibility for oversight.

This proposed multiplication of oversight responsibility for oil drilling would occur on a single level of authority; each of the authorities would have a somewhat different function but would be equal in the sense that neither would oversee the other. The type of structure is what may be called horizontal responsibility for oversight. Such a structure could of course create a problem of coordination, and potentially give rise to conflicts. Those problems could be mitigated by rules requiring regular consultation and joint meetings, and specifying which body takes priority in cases of conflict.

Rules of this kind could also obviate the need to establish a higher authority to oversee both bodies, which would create a further problem. It would in effect introduce a form of vertical responsibility to the structure. The problem with vertical oversight responsibility is that it tends to duplicate functions at each level, recreating the many hands problem. It also invites a reiteration of the question who will oversee the overseers, generating a regress of oversight that has no logical termination (Thompson, 2005, pp. 261-62). However, the vertical model may be necessary in some cases, and with the appropriate modifications can avoid these problems, as a consideration of the failures of responsibility in the financial crisis beginning in 2007 will illustrate.

\section{Failed Banks}

The financial crisis that plunged the world economy into the worst depression since the 1930s was set off when the housing bubble burst and a liquidity shortage developed in the U.S. in 2007. Major financial institutions collapsed, national governments had to bail out banks, stock markets fell dramatically, the housing market collapsed in many 
areas, and economic activity including employment declined disastrously. The recovery, still fragile as late as 2011, was by all measures slow. Such a immense and complex calamity had many causes, and not surprisingly the list of individuals and organizations that could be plausibly blamed is distressingly long. ${ }^{13}$ Among the candidates: the mortgage lenders who exploited the sub-prime market, the underwriters who engaged in negligent and fraudulent practices, the officials and others who encouraged deregulation, the economists and others who promoted free market ideology, the investment bankers who took risks they did not understand, the rating agencies who gave their approval to junk securities, the government lenders (Fannie \& Freddie) who bought up most of the high risk mortgage-backed securities, the government regulators who failed to see the signs of trouble and then failed to act when they did. The crisis manifests the problem of many hands in its most florid form.

The most prominent of the many investigations was conducted by the Financial Crisis Inquiry Commission, created in July 2009 by Congress, which appointed all 10 of its members (Financial Crisis Inquiry Commission, 2010a). The members had considerable expertise in financial matters, but not much independence from their political supporters. Unlike the 9/11 Commission, it split along partisan lines and did not issue a unanimous final report (Financial Crisis Inquiry Commission, 2011). One reason was that the Commission became embroiled in trying to decide what was the most important cause of the crisis. The Democrats tended to blame Wall Street; the Republicans, the U.S. government (Freddie and Fannie) and European economies. The majority report made some effort to identify individuals and institutions who were responsible but included so many culprits that the minority report was provoked to object: "When everything is important, nothing is" (Financial Crisis Inquiry Commission, 2011, p. 414). Yet the "ten essential causes" summarized in the minority report itself emphasized broad impersonal forces, such as the credit bubble in the world economy, giving less attention to the role of individual decision makers (Financial Crisis Inquiry Commission, 2011, pp. 417-419). Nevertheless, the Commission's report contains information and analyses that are helpful in examining the failure of design responsibility in this case and potential changes to prevent such failures in the future.

Although a full assessment of responsibility for the crisis would examine many hands, one set of institutions - the rating agencies-merit special attention. Among the rich array of possible culprits, these agencies best serve to show illustrate how the vertical model for designing oversight responsibility might be applied. The agencies, which include once respected organizations such as Moody's and Standard and Poor's, were not the best known villains in 
the popular exposes of the crisis, but their failures, most observers including both the majority and minority members of the Commission now agree, contributed significantly to the crisis (Financial Crisis Inquiry Commission, 2011, pp. 43-44, p. 212, p. 426, p. 418; Financial Crisis Inquiry Commission, 2010b). The agencies were the "reputational intermediaries" who enabled the banks to persuade investors that the securities were safe (Walter, 2010). The job of the agencies was to assess the relative risks of various securities. Investors, investment banks, and the government relied on their assessments. As financial instruments became more complicated, their ratings became even more important, and even more lucrative for the agencies. They gave their highest rating to some of the most risky asset-based securities (such as the sub prime mortgages bundled as securities that obscured their origin). The Commission majority concluded: "the failures of credit rating agencies were essential cogs in the wheel of financial destruction. The three credit rating agencies were key enablers of the financial meltdown" (Financial Crisis Inquiry Commission, 2011, p. xxv).

Could agency executives have recognized the risk sooner? Even if they were unaware (and some surely were not), their ignorance does not seem excusable. Some of their own analysts knew that they were giving high ratings to nearly worthless securities (Lowenstein, 2008; and U.S. Senate, 2010). If they knew or should have known, could they have downgraded the securities sooner? Or could they legitimately claim that they "had no choice"? The pressure from the investment banks to give high ratings was relentless. The business of rating these securities was lucrative; it accounted for nearly half of Moody's revenue in the year before the collapse. But the agencies could have revised their ratings — as they eventually did anyhow, and with worse consequences for everyone.

It would be possible to identify the individuals who were responsible, but for purposes organizational design that effort should be in the service of locating the structural problems that contributed to the failure. The most salient problem is another institutional conflict of interest - not the functional conflict we saw in the case of the MMS in oil drilling, but a classic financial one. The rating agencies' interest in providing accurate assessments conflicts with their interest in financial gain. Any agency that declined to give good ratings to the securities that their client eagerly wanted to sell would soon lose that client and probably others.

Some observers and some insiders recognized this structural problem, as well as other flaws in the regulatory system, well before the financial collapse (Financial Crisis Inquiry Commission, p. 2011, pp. 211-212; Office of Special Inspector General, 2009, pp. 136-137; Lynch, 2009). ${ }^{14}$ Congress tried to address some of the problems by 
enacting the Credit Ratings Agency Reform Act in 2006, which strengthened the authority of the SEC. But the same Act prohibited the SEC from examining the substance of the ratings and the procedures for arriving at them (Lynch, 2009). As a sign that the Act did change the fundamental conflicted relationship between the agencies and the banks, the agencies themselves supported the legislation.

Some of the agencies have now taken steps to minimize this conflict—for example, by establishing greater internal separation of the business departments from the rating analysts (Standard and Poor's, 2008). Congress has enacted legislation (the Dodd-Frank Act) that reinforces these steps and also strengthens the SEC's enforcement powers in this area (U.S. Congress, 2010). The legislation creates an Office of Credit Ratings at the SEC with expertise and its own compliance staff and the authority to fine agencies. But the conflict remains because the banks pay the agencies who rate the products the banks want to sell to investors. Investors have no incentive to pay for their own ratings (which are not confidential and could be easily used by other free riding investors). The government is not in a position to take over the rating process itself, or even oversee it at any depth. Under these challenging circumstances, how could responsibility for monitoring the ratings be designed into the system?

A proposal described in an amendment to the Dodd-Frank bill, adopted by the Senate but dropped in the final legislation, would go some way toward addressing the problem (Congressional Record, 2010; and Herszenhorn, 2010). It would require every new asset-based bond issue to be rated not by a rating agency chosen by the investment bank issuing the security but by an agency assigned by a new independent board composed of investors and others in the industry and governed by federal rules. The board would choose the agency based on its competence and performance. The agencies would still be paid by the banks, but the banks could not shop around for their preferred ratings. They would pay the agency regardless of whether they liked the ratings. This structure would thus eliminate or at least drastically mitigate the conflict of interest.

For our purposes the significance of the proposal lies in the way the oversight responsibility is designed. It is assigned to the independent board, not for reviewing the ratings themselves, not even for overseeing the practices of the rating agencies in their day-to-day business, but for maintaining standards intended to encourage agencies to produce accurate ratings. It is a version of the vertical model of responsibility mentioned above, but without the duplication of function and potential regress that less differentiated versions of the model can generate. It also preserves individual responsibility. The hands (or minds) that choose the agencies are identifiable, and they produce 
a record that could be used to identify the individuals in any agency who are not following best practices. Having this kind of responsibility regime in place should reduce the likelihood that blame would have to be assigned in the future because it increases the incentives for blameless behavior in the present.

\section{Conclusion}

The problem of many hands is inherent in any complex organization. The outcomes that organizations produce are the result of decisions and non-decisions by many different individuals, most of whose contributions may be minimal and unintended. Yet to assign responsibility for an organizational outcome fairly and effectively, we have to identify individuals who knowingly and freely contribute to it. We can go further than is usually assumed in identifying responsible individuals even in large-scale organizational disasters if we adjust the standard criteria of moral responsibility so that they are more suitable for assessing organizational decision making. This individualist approach is necessary, we have seen, even if the purpose is not to punish or discipline individuals but to make changes in the organization to reduce the chances of adverse outcomes in the future. We use the results of the investigation into responsibility for past outcomes as a guide for changing an organization to clarify individual responsibility for future outcomes and future oversight. Specifying the responsibility for monitoring the reforms in the structures of responsibility — design responsibility—is often neglected but is no less important than the responsibility for outcomes.

The commissions that examined 9/11, the Deepwater Horizon oil spill, and the financial crisis were in effect engaged in this kind of investigation—identifying past failures of responsibility to prevent future ones. They were successful insofar as they were independent and knowledgeable. Notice that these are institutional variants of the criteria of individual responsibility. We assess the responsibility of the commissions with criteria analogous to those by which they should assess the responsibility officials. Some of the commissions' recommendations are too general to count as designing responsibility (for example, avoiding the "failure of imagination"). But others are explicitly intended to strengthen individual responsibility in the organization itself in the future (the new director of National Intelligence, for example). Most significant for our purposes were the proposals to establish oversight bodies, such as the citizens' advisory council for oil drilling or the independent board for choosing rating agencies. The council, an example of a horizontal oversight, would bring a different perspective to balance government experts and 
industry executives. The board illustrates how vertical oversight can avoid the duplication and regress in designs that address the problem of many hands by multiplying the hands.

Whatever their other functions, oversight bodies such as these could be charged with holding individuals in the organization responsible on a continuing basis, and most importantly with exposing organizational defects that obstruct individual responsibility. They would in effect take responsibility for designing responsibility.

Commissions and oversight bodies, properly constituted, can be important devices for mitigating the problem of many hands, but no less important is the rationale for establishing such institutions. We would be better able to identify the individuals who contribute to the failures of organizations and thereby reduce the chances of future failures if we refine the criteria of responsibility and extend their scope to encompass the organizational design. This modified individualist approach to the problem of many hands can serve as a guide in the continuing effort to find ways to strengthen individual responsibility in modern society. 


\section{References}

Allen, A., \& Mintrom, M. (2010). Responsibility and school governance, Education Policy, 24(3), 439-464.

Applegate, J. S. (1998). Beyond the usual suspects: The use of citizens advisory boards in environmental decisionmaking, Indiana Law Journal, 73(3), 903-57.

Aristotle. (1963). The works of Aristotle: Ethica Nicomachea,. W.D. Ross (Ed.). Oxford: Oxford University Press.

Becquart-Leclercq, J. (1982). Absolute values and practical problems: dilemmas of local politics in France, International Political Science Review, 3(2), 218-229.

Black, J. (2008). Constructing and contesting legitimacy and accountability in polycentric regulatory regimes, Regulation \& Governance, 2(2), 137-164.

Bluhm, W. and R. A. Heineman. (2007). Ethics and public policy: methods and cases. Upper Saddle River NJ: Pearson Prentice Hall.

Boin, A., Hart, P. T., McConnell, A., \& Preston, T. (2010). Leadership style, crisis response and blame management: the case of Hurricane Katrina, Public Administration, 88(3), 706-723.

Bovens, M. (1998). The quest for responsibility: accountability and citizenship in complex organisations. Cambridge: Cambridge University Press.

Bovens, M. (2005). Public accountability. In Ferlie, E., Lynne, L., \& C. Pollitt (Eds.), The Oxford handbook of public management. Oxford: Oxford University Press, pp. 182-208.

Bovens, M. (2007). Analysing and assessing accountability: A conceptual framework, European Law Journal, $13(4), 447-468$.

Bovens, M. (2010). Two concepts of accountability: accountability as a virtue and as a mechanism, West European Politics, 33(5), 946-967.

Broder, J. M. (2011, January 5). Blunders abounded before gulf spill, panel says. New York Times. Retrieved from http://www.nytimes.com/2011/01/06/science/earth/06spill.html 
Burke, J. P. (1986). Bureaucratic responsibility. Baltimore: John Hopkins University Press.

Christensen, T., \& Laegreid, P. (2002). New public management: puzzles of democracy and the influence of citizens, Journal of Political Philosophy, 10(3), 267-95.

Cohen, S., \& Grace, D. (1994). Engineers and social responsibility: an obligation to do good, IEEE Technology and Society Magazine, IEEE, 13(3), 12-19.

Congressional Record. (2010). Bill Summary and Status (S. Amdt. 3991111 th Congress, May 12). Retrieved from http://homas.loc.gov/cgi-bin/bdquery/z?d111:SP03991: $\{$ Editor: colon is necessary\}

DeMartino, G. F. (2011). The economist's oath: on the need for and content of professional economic ethics. Oxford: Oxford University Press.

Denton, M., \& Flinders, M. (2006). Democracy, devolution and delegated governance in Scotland, Regional and Federal Studies, 16(1), 63-82.

DiIulio Jr., J. J. (1988). What's wrong with private prisons, The Public Interest, 92, 66-83.

Dobel, J. P. (1990). Integrity in the public service, Public Administration Review, 50(3), 354-366.

Dobel, J. P. (1999). The ethics of resigning, Journal of Policy Analysis and Management, 18(2), $245-263$.

Donagan, A. (1977). The theory of morality. Chicago: University of Chicago Press.

Doorn, N. (2009). Responsibility ascriptions in technology development and engineering: three perspectives, Science and Engineering $\quad$ Ethics, $\quad$ 18(1), http://www.springerlink.com/content/3354167367622265/fulltext.pdf

Doorn, N., \& Fahlquist, J. N. (2010). Responsibility in engineering: toward a new role for engineering ethicists, Bulletin of Science, Technology\& Society, 30(3), 222-230.

Dubnick, M. J.(2003). Accountability and ethics: reconsidering the relationships, International Journal of Organization Theory and Behavior, 6(3), 405-441.

Falkenrath, R. A. (2004). The 9/11 Commission Report: A Review Essay. International Security, 29(3), $170-190$.

Feinberg, J. (1970). Doing and deserving. Princeton, N.J.: Princeton University Press. 
Financial Crisis Inquiry Commission. (2010a). About the commission. Retrieved from http://www.fcic.gov/about/

Financial Crisis Inquiry Commission. (2010b). Credit ratings and the financial crisis', Preliminary Staff Report (June 2). Retrieved from http://www.fcic.gov/reports/pdfs/2010-0602-Credit-Ratings.pdf

Financial Crisis Inquiry Commission. (2011). The financial crisis inquiry report: final report of the national commission on the causes of the financial and economic crisis in the United States. Washington, DC: U.S. Government Printing Office. (January). Retrieved from http://fcic.law.stanford.edu/report

French, P. A. (Ed.) (2006) Collective responsibility, Midwest Studies in Philosophy, 30.

Glover, J. (1970). Responsibility. London: Routledge and Kegan Paul.

Hart, H. L. A., \& Honoré, A. M. (1959). Causation in the law. Oxford, England: Clarendon Press.

Herszenhorn, D. M. (2010, June 15). House-Senate talks drop new credit-rating rules. New York Times. Retrieved from http://www.nytimes.com/2010/06/16/business/16regulate.html

Hildreth, W. B. (1983). Applying professional disclosure standards to productivity financial analyses, Public Productivity Review, 7(3), 269-87.

Johnson, S., \& Kwak, J. (2011). 13 bankers: the wall street takeover and the next financial meltdown. New York: Vintage.

Jos, P. H. (1988). Moral autonomy and the modern organization, Polity, 21, 321-44.

Kane, Robert (Ed.) 2002. Oxford handbook on free will. New York: Oxford University Press.

Kaptein, M. (1998). Ethics management: auditing and developing the ethical content of organizations. Dordrecht: Kluwer.

Kaufman, H. (1977). Red tape: its origins, uses and abuses. Washington DC: Brookings.

Leichter, H. M. (1992). Political accountability in health care rationing: In search of a new Jerusalem, University of Pennsylvania Law Review, 140(5), 1939-1963.

Lowenstein, R. (2008, April 27). Triple-A failure: the ratings game. New York Times Magazine. Retrieved from http://www.nytimes.com/2008/04/27/magazine/27Credit-t.html?pagewanted=print 
Luban, D., Strudler, A., \& Wasserman, D. (1992). Moral responsibility in the age of bureaucracy, Michigan Law Review, 90(8), 2348-2392.

Lynch, T. E. (2009). Deeply and persistently conflicted: credit rating agencies in the current regulatory environment, Case Western Reserve University Law Review, 59, 232-233.

Mastop, R. (2010). Characterising responsibility in organisational structures: The problem of many hands. In Governatori, G., \& Sartor, G. (Eds.), Deontic logic in computer science (pp. 274-287). Berlin Heidelberg: Springer-Verlag.

May, E. R. (2007). Introduction. In May, E. R., The 9/11 Commission Report with related documents (pp.1-26) Boston and New York: Beford/St. Martin's.

May, L., \& Hoffman, S. (Eds.). (1992). Collective responsibility: five decades of debate in theoretical and applied ethics. Lanham MD: Rowman \& Littlefield.

May, E. R., Zelikow, P., \& Falkenrath, R. A. (2005). Correspondence: sins of commission? Falkenrath and his critics, International Security, 29(4), 208-211.

McClean, B., \& Nocera, J. (2010). All the devils are here: The hidden history of the financial crisis. New York: Penguin Group.

McGraw, K. M. (1990). Avoiding blame: an experimental investigation of political excuses and justifications, British Journal of Political Science, 20(01), 119-142.

McGraw, K. M. (1991). Managing blame: an experimental test of the effects of political accounts, The American Political Science Review, 85(4), 1133-1157.

McNay, D. (2010, November 15). All the devils are here: best business book of the year. Huffington Post. Retrieved from http://www.huffingtonpost.com/don-mcnay/all-the-devils-are-here-b_b_783923.html

Miller, S. (2006). Collective Moral Responsibility: An Individualist Account. Midwest Studies in Philosophy, 30(1), 176-193.

Mulgan, R. (2002). On ministerial resignations (and the lack thereof), Australian Journal of Public Administration, $61(2), 121-127$. 
National Commission on BP Deepwater Horizon Oil Spill and Offshore Drilling, (2011). Deep Water: The Gulf Oil Disaster and the Future of Offshore Drilling, Report to the President. Washington D.C.: Government Printing Office.

National Commission on Terrorist Attacks upon the United States. (2004). The 9/11 commission report: Final report of the National Commission on Terrorist Attacks upon the United States. Washington, DC: Government Printing Office.

Nissenbaum, H. (1996). Accountability in a computerized society, Science and Engineering Ethics, 2(1), 25-42.

Office of the Special Inspector General for the Troubled Asset Relief Program. (2009, October 21). Quarterly Report to Congress. Retrieved from http://www.sigtarp.gov/reports.shtml

Pereboom, D. (Ed.) (2009). Free will. Indianapolis: Hackett Publishing.

Pesch, U. (2008). Administrators and accountability: the plurality of value systems in the public domain, Public Integrity, 10(4), 335-344.

Petter, J. (2005). Responsible behavior in bureaucrats: an expanded conceptual framework, Public Integrity, 7(3), 197-217.

Pettit, P. (2007). Responsibility incorporated, Ethics, 117(2), 171-201.

Quiggin, J. (2010). Zombie economics: how dead ideas still walk among us. Princeton: Princeton University Press.

Rich, W. (1996). The moral choices of garbage collectors: administrative ethics from below, American Review of Public Administration, 26(2), 201-212.

Scanlon, T M. (1998). What we owe to each other. Cambridge MA: Harvard University Press.

Schedler, A. (1998). The normative force of electoral promises. Journal of Theoretical Politics, 10 (2), 191-214.

Walter, E. B. (2010). Plans and Prospects for Financial Regulatory Reform, Speech by SEC Commissioner, UC San Diego, April 23). Retrieved from http://www.sec.gov/news/speech/2010/spch042310ebw.htm

Shenon, P. (2008). The Commission: an uncensored history of the 9/11 investigation. New York: Hatchette Book Group. 
Smiley, M. (1992). Moral responsibility and the boundaries of community: power and accountability from a pragmatic point of view. Chicago: University of Chicago Press.

Smiley, M. (2011). Collective responsibility. In Zalta, E. N. (Ed.) The Stanford Encyclopedia of Philosophy. Retrieved from http://plato.stanford.edu/archives/spr2011/entries/collective-responsibility/.

Sorabji, R. (1980). Necessity, cause and blame: perspectives on Aristotle's theory. Ithaca: Cornell University Press.

Sorkin, A. R. (2009). Too big to fail: the inside story of how WallSstreet and Washington fought to save the financial system - and themselves. New York: Viking.

Standard and Poor's. (2008, February 7). S\&P's steps to further manage potential conflicts of interest, strengthen the ratings process, and better serve the markets. Retrieved from http://media.corporateir.net/media files/irol/96/96562/sp leadership.pdf $\{$ editor?\}

Steiker, C. S., \& Steiker, J. M. (1995). Sober second thoughts: reflections on two decades of constitutional regulation of capital punishment, Harvard Law Review, 109(2), 355-438.

Sullivan, H. (2003). New forms of local accountability: coming to terms with 'many hands'?, Policy \& Politics, 31(3), 353-369.

Thompson, D. (1980). The moral responsibility of public officials: the problem of many hands, American Political Science Review, 74(4), 905-916.

Thompson, D. (1987). Political ethics and public office. Cambridge, MA: Harvard University Press.

Thompson, D. (2005). Restoring responsibility: ethics in government, business and healthcare. Cambridge: Cambridge University Press.

Tong, R. (1985). Ethics in policy analysis. Upper Saddle River NJ: Prentice-Hall.

U.S. Congress. (2010, January 5). Dodd-Frank Wall Street Reform and Consumer Protection Act, H. R. 4173, Title IX, subtitle C. 11th Cong., 2nd sess. Retrieved fromhttp://thomas.loc.gov/cgi-bin/query/z?c111:H.R.4173: \{Editor: colon is necessary\}

U.S. Department of Defense. (2003). News Briefing - Secretary Rumsfeld and Gen. Myers, April 11, 2003. Retrieved from http://www.defense.gov/transcripts/transcript.aspx?transcriptid=2367 
U.S. Secretary of the Interior. (2010, May 19) Establishment of the Bureau of Ocean Energy Management, the Bureau of Safety and Environmental Enforcement, and the Office of Natural Resources Revenue. Retrieved from http://elips.doi.gov/app_so/act_getfiles.cfm?order_number=3299

U.S. Securities and Exchange Commission. (2011). Credit rating agencies, Retrieved from http://www.sec.gov/spotlight/dodd-frank/creditratingagencies.shtml

U.S. Senate. (2010, April 23). Permanent Subcommittee on Investigations, Committee on Homeland Security and Governmental Affair, Hearings on Wall street and the financial crisis: the role of credit rating agencies, Exhibit List. Retrieved from http://hsgac.senate.gov/public/_files/Financial_Crisis/042310Exhibits.pdf

Urbina, I. (2010, June 5). In Gulf, it was unclear who was in charge of rig, New York Times. Retrieved from http://www.nytimes.com/2010/06/06/us/06rig.html?scp=1\&sq=\%22who\%20was\%20in $\% 20$ charge $\% 20$ of $\% 20$ rig $\% 22 \& \mathrm{st}=\mathrm{cse}$

Van de Poel, I. (2008). How should we do nanoethics? A network approach for discerning ethical issues in nanotechnology, NanoEthics, 2(1), 25-38.

Van de Poel, I., \& Zwart, S. D. (2010). Reflective equilibrium in R \& D networks, Science, Technology, \& Human Values, 35(2), 174-99.

Van der Heijden, J. (2010). On peanuts and monkeys: private sector involvement in Australian building control, Urban Policy and Research, 28(2), 195-210.

Van Gorp, A. (2005). Ethical issues in engineering ethics: safety and sustainability. Delft, Netherlands: Delft University of Technology and Eindhoven University of Technology.

Wachs, M. (1990). Ethics and advocacy in forecasting for public policy. Business \& Professional Ethics Journal, 9 $(1 / 2), 141-157$.

Walzer, M. (1973). Political action: the problem of dirty hands, Philosophy \& Public Affairs, 2(2), 160-180.

Wempe, J.F.D.B. (1998). Market and morality: business ethics and the dirty and many hands dilemma. Amsterdam: Eburon. 
West, E. (2000). Organisational sources of safety and danger: sociological contributions to the study of adverse events, Quality in Health Care, 9(2), 120-126.

White House Press Office (2010). President Obama announces members of the BP Deepwater Horizon Oil Spill and Offshore Drilling Commission. Retrieved from http://www.whitehouse.gov/the-press-office/president-obamaannounces-members-bp-deepwater-horizon-oil-spill-and-offshore-drill

Zwart, S. D., Van de Poel, I., Van Mil, H., \& Brumsen, M. (2006). A network approach for distinguishing ethical issues in research and development, Science and Engineering Ethics, 12(4), 663-684. 


\section{Notes}

*An earlier shorter version of this chapter appeared in the American Review of Public Administration [vol. and number to come] 2014.

${ }^{1}$ The responsibility-denying phrase comes from Secretary of Defense Donald Rumsfeld, defending the military response to looting and disorder in Baghdad after the U.S. invasion: "Think what's happened in our cities when we've had riots, and problems, and looting. Stuff happens!” (U.S. Department of Defense, 2003).

${ }^{1}$ The problem was first analyzed in this way in Thompson (1980, revised, 1987, reprinted 2005). The phrase alludes to the metaphor of "dirty hands" (Walzer, 1973). The "many hands" articles have generated a large literature that continues to grow. The most extended discussions are by Bovens $(2010,2007,2005,1998)$, who carries the analysis further and proposes responses to the problem that are consistent with Thompson; and Smiley (1992), who criticizes Thompson's conceptual criteria for responsibility. A formal analysis of the problem is given by Mastop (2010). The Thompson formulation of the problem has proved relevant in a wide range of subjects and disciplines: blame attribution (McGraw, 1991,1990); city planning forecasting (Wachs, 1990); computing accountability (Nissenbaum, 1996); corporate management (Wempe, 1998; Kaptein, 1998); crisis management (Boin, et al. 2010); engineering (Doorn and Fahlquist 2010; Doorn, 2012; van Gorp, 2005; Cohen and Grace, 1994); criminal justice (Steiker and Steiker, 2005; DiIulio, 1988); European law (Bovens, 2007); financial analysis (Hildreth 1983); garbage collection ethics (Rich, 1991); government regulation (Black, 2008); healthcare (West, 2000; Leichter, 1992), European local government (Denton and Flinders, 2006; Sullivan, 2003; Becquart-Leclercq, 1982); law of war (Bluhm and Heineman, 2007, 313-15, 218); nanoethics (van de Poel, 2008); political campaigning (Schedler 1998); professional ethics (DeMartino 2011, 133-34); public administration (van der Heijden, 2010; Pesch, 2008; Petter 2005; Christensen and Laegreid, 2002; Dobel, 1990; Burke, 1986; and Tong, 1985, 67-73); organization theory (Dubnick, 2003; Jos, 1988); research and development networks (van de Poel and Zwart, 2010); resignation in protest (Mulgan, 2002; Dobel, 1999); school governance (Allen and Mintrom, 2010); and technology assessment (Zwart et al., 2006)..

1. "With regular incantations of 'I accept full responsibility,' an official strengthens his or her own political standing — by reassuring the public that someone is in charge and by projecting an image of a courageous leader who 
does not pass the buck.... the ritual often quells public debate about a controversial decision or policy, effectively blocking further inquiry into the genuine moral responsibility of all of the officials involved..." (Thompson, 1980, 907).

${ }^{1}$ An important exception is Miller (2006) who has developed a cogent individualist account of collective responsibility.

1. For a discussion of how under certain conditions collectivities can be morally blamed even if they are not properly regarded as human agents: see Scanlon, 2008, pp. 160-66.

${ }^{1}$ Unlike many proponents of collective agency, Pettit (2007) explicitly insists that his account is consistent with individual responsibility: "The regime I envisage would hold individual enactors responsible for any harm that they might have refused to do and didn't' (p. 197).

${ }^{1}$ In addition to Bovens $(2010 ; 2007 ; 1998)$ and Thompson $(2005 ; 1987 ; 1980)$, see Luban et al. (1992).

${ }^{1}$ These criteria raise notoriously difficult philosophical issues, only a few of which are mentioned here. In addition to the contemporary works cited in the notes that follow, see the classic source, which is still the most suggestive: Aristotle 1993, Bk. III. 1-5. Also see Sorabji (1980).

${ }^{1}$ The interpretation of the criterion is not only more complex than can be indicated here, but it is also a chief point of controversy between two of the best works in the theory of responsibility. (cf. Hart \& Honoré, 1959, pp. 61-62, pp. 116-17, pp. 103-22; Feinberg, 1970, p. 184, pp. 201-07). The interpretation here more closely follows Feinberg.

${ }^{1}$ Notice that the cause can take various forms, such as being a necessary element in some set of conditions generally connected with the harm, operating as someone's reason for doing something harmful, constituting an opportunity for doing the harm or denying a safeguard against the harm (Hart \& Honoré, 1959, p. 122).

${ }^{1}$ A political theorist has many excuses, some of which might even be valid, for disregarding the relevant but complex metaphysical problems raised by this criterion. For a sample of the problems and various approaches to addressing them, see Pereboom (2009); and Kane (2002).

${ }^{1}$ A notable exception to the Commission's tendency to avoid assigning individual blame is its pointed criticism of CIA Director George Tenet for failing to undertake the organizational reform that arguably could have avoided some of the mistakes that led to the disaster (National Commission on Terrorist Attacks, 2004, 358). 
${ }^{1}$ The book that identifies the most hands is appropriately titled: All the Devils are Here (McLean \& Nocera, 2010). As one reviewer wrote: "Some of us want to tie the financial crisis to Wall Street and Washington. Others want to blame greedy and ill-informed consumers, rouge traders and brokers, out-of-control lenders and people with a Pollyanna view of the world. McLean and Nocera make a convincing argument that it's all of the above. And more" (McNay, 2010). Other useful discussions of the crisis include Johnson \& Kwak (2011); Quiggin (2010); and Sorkin (2009).

${ }^{1}$ For an insider's view, see Jerome S. Fons, Former Managing Director of Credit Policy, Moody’s Investor Services, Testimony to Congress, U.S. House of Representatives, Committee on Oversight and Government Reform, Hearing: Credit Rating Agencies and the Financial Crisis, October 23 2008, quoted in Office of Special Inspector General (2009, p. 136). 


\section{References}

Allen, A., \& Mintrom, M. (2010). Responsibility and school governance, Education Policy, 24(3), 439-464.

Applegate, J. S. (1998). Beyond the usual suspects: The use of citizens advisory boards in environmental decisionmaking, Indiana Law Journal, 73(3), 903-57.

Aristotle. (1963). The works of Aristotle: Ethica Nicomachea,. W.D. Ross (Ed.). Oxford: Oxford University Press.

Becquart-Leclercq, J. (1982). Absolute values and practical problems: dilemmas of local politics in France, International Political Science Review, 3(2), 218-229.

Black, J. (2008). Constructing and contesting legitimacy and accountability in polycentric regulatory regimes, Regulation \& Governance, 2(2), 137-164.

Bluhm, W. and R. A. Heineman. (2007). Ethics and public policy: methods and cases. Upper Saddle River NJ: Pearson Prentice Hall.

Boin, A., Hart, P. T., McConnell, A., \& Preston, T. (2010). Leadership style, crisis response and blame management: the case of Hurricane Katrina, Public Administration, 88(3), 706-723.

Bovens, M. (1998). The quest for responsibility: accountability and citizenship in complex organisations. Cambridge: Cambridge University Press.

Bovens, M. (2005). Public accountability. In Ferlie, E., Lynne, L., \& C. Pollitt (Eds.), The Oxford handbook of public management. Oxford: Oxford University Press, pp. 182-208.

Bovens, M. (2007). Analysing and assessing accountability: A conceptual framework, European Law Journal, 13(4), 447-468.

Bovens, M. (2010). Two concepts of accountability: accountability as a virtue and as a mechanism, West European Politics, 33(5), 946-967. 
Broder, J. M. (2011, January 5). Blunders abounded before gulf spill, panel says. New York Times. Retrieved from http://www.nytimes.com/2011/01/06/science/earth/06spill.html

Burke, J. P. (1986). Bureaucratic responsibility. Baltimore: John Hopkins University Press.

Christensen, T., \& Laegreid, P. (2002). New public management: puzzles of democracy and the influence of citizens, Journal of Political Philosophy, 10(3), 267-95.

Cohen, S., \& Grace, D. (1994). Engineers and social responsibility: an obligation to do good, IEEE Technology and Society Magazine, IEEE, 13(3), 12-19.

Congressional Record. (2010). Bill Summary and Status (S. Amdt. 3991 111th Congress, May 12). Retrieved from http://thomas.loc.gov/cgi-bin/bdquery/z?d111:SP03991: \{Editor: colon is necessary\}

DeMartino, G. F. (2011). The economist's oath: on the need for and content of professional economic ethics. Oxford: Oxford University Press.

Denton, M., \& Flinders, M. (2006). Democracy, devolution and delegated governance in Scotland, Regional and Federal Studies, 16(1), 63-82.

DiIulio Jr., J. J. (1988). What's wrong with private prisons, The Public Interest, 92, 66-83.

Dobel, J. P. (1990). Integrity in the public service, Public Administration Review, 50(3), 354-366.

Dobel, J. P. (1999). The ethics of resigning, Journal of Policy Analysis and Management, 18(2), 245-263.

Donagan, A. (1977). The theory of morality. Chicago: University of Chicago Press.

Doorn, N. (2009). Responsibility ascriptions in technology development and engineering: three perspectives, $\begin{array}{lllll}\text { Science } & \text { and } & \text { Engineering } & \text { 6thics, } & \text { 69-90. }\end{array}$ http://www.springerlink.com/content/3354167367622265/fulltext.pdf

Doorn, N., \& Fahlquist, J. N. (2010). Responsibility in engineering: toward a new role for engineering ethicists, Bulletin of Science, Technology\& Society, 30(3), 222-230.

Dubnick, M. J.(2003). Accountability and ethics: reconsidering the relationships, International Journal of Organization Theory and Behavior, 6(3), 405-441. 
Falkenrath, R. A. (2004). The 9/11 Commission Report: A Review Essay. International Security, 29(3), 170-190.

Feinberg, J. (1970). Doing and deserving. Princeton, N.J.: Princeton University Press.

Financial Crisis Inquiry Commission. (2010a). About the commission. Retrieved from http://www.fcic.gov/about/

Financial Crisis Inquiry Commission. (2010b). Credit ratings and the financial crisis', Preliminary Staff Report (June 2). Retrieved from http://www.fcic.gov/reports/pdfs/2010-0602-Credit-Ratings.pdf

Financial Crisis Inquiry Commission. (2011). The financial crisis inquiry report: final report of the national commission on the causes of the financial and economic crisis in the United States. Washington, DC: U.S. Government Printing Office. (January). Retrieved from http://fcic.law.stanford.edu/report

French, P. A. (Ed.) (2006) Collective responsibility, Midwest Studies in Philosophy, 30.

Glover, J. (1970). Responsibility. London: Routledge and Kegan Paul.

Hart, H. L. A., \& Honoré, A. M. (1959). Causation in the law. Oxford, England: Clarendon Press.

Herszenhorn, D. M. (2010, June 15). House-Senate talks drop new credit-rating rules. New York Times. Retrieved from http://www.nytimes.com/2010/06/16/business/16regulate.html

Hildreth, W. B. (1983). Applying professional disclosure standards to productivity financial analyses, Public Productivity Review, 7(3), 269-87.

Johnson, S., \& Kwak, J. (2011). 13 bankers: the wall street takeover and the next financial meltdown. New York: Vintage.

Jos, P. H. (1988). Moral autonomy and the modern organization, Polity, 21, 321-44.

Kane, Robert (Ed.) 2002. Oxford handbook on free will. New York: Oxford University Press.

Kaptein, M. (1998). Ethics management: auditing and developing the ethical content of organizations. Dordrecht: Kluwer.

Kaufman, H. (1977). Red tape: its origins, uses and abuses. Washington DC: Brookings.

Leichter, H. M. (1992). Political accountability in health care rationing: In search of a new Jerusalem, University of Pennsylvania Law Review, 140(5), 1939-1963. 
Lowenstein, R. (2008, April 27). Triple-A failure: the ratings game. New York Times Magazine. Retrieved from http://www.nytimes.com/2008/04/27/magazine/27Credit-t.html?pagewanted=print

Luban, D., Strudler, A., \& Wasserman, D. (1992). Moral responsibility in the age of bureaucracy, Michigan Law Review, 90(8), 2348-2392.

Lynch, T. E. (2009). Deeply and persistently conflicted: credit rating agencies in the current regulatory environment, Case Western Reserve University Law Review, 59, 232-233.

Mastop, R. (2010). Characterising responsibility in organisational structures: The problem of many hands. In Governatori, G., \& Sartor, G. (Eds.), Deontic logic in computer science (pp. 274-287). Berlin Heidelberg: Springer-Verlag.

May, E. R. (2007). Introduction. In May, E. R., The 9/11 Commission Report with related documents (pp.1-26) Boston and New York: Beford/St. Martin's.

May, L., \& Hoffman, S. (Eds.). (1992). Collective responsibility: five decades of debate in theoretical and applied ethics. Lanham MD: Rowman \& Littlefield.

May, E. R., Zelikow, P., \& Falkenrath, R. A. (2005). Correspondence: sins of commission? Falkenrath and his critics, International Security, 29(4), 208-211.

McClean, B., \& Nocera, J. (2010). All the devils are here: The hidden history of the financial crisis. New York: Penguin Group.

McGraw, K. M. (1990). Avoiding blame: an experimental investigation of political excuses and justifications, British Journal of Political Science, 20(01), 119-142.

McGraw, K. M. (1991). Managing blame: an experimental test of the effects of political accounts, The American Political Science Review, 85(4), 1133-1157.

McNay, D. (2010, November 15). All the devils are here: best business book of the year. Huffington Post. Retrieved from http://www.huffingtonpost.com/don-mcnay/all-the-devils-are-here-b_b_783923.html

Miller, S. (2006). Collective Moral Responsibility: An Individualist Account. Midwest Studies in Philosophy, 30(1), 176-193. 
Mulgan, R. (2002). On ministerial resignations (and the lack thereof), Australian Journal of Public Administration, 61(2), 121-127.

National Commission on BP Deepwater Horizon Oil Spill and Offshore Drilling, (2011). Deep Water: The Gulf Oil Disaster and the Future of Offshore Drilling, Report to the President. Washington D.C.: Government Printing Office.

National Commission on Terrorist Attacks upon the United States. (2004). The 9/11 commission report: Final report of the National Commission on Terrorist Attacks upon the United States. Washington, DC: Government Printing Office.

Nissenbaum, H. (1996). Accountability in a computerized society, Science and Engineering Ethics, 2(1), 25-42.

Office of the Special Inspector General for the Troubled Asset Relief Program. (2009, October 21). Quarterly Report to Congress. Retrieved from http://www.sigtarp.gov/reports.shtml

Pereboom, D. (Ed.) (2009). Free will. Indianapolis: Hackett Publishing.

Pesch, U. (2008). Administrators and accountability: the plurality of value systems in the public domain, Public Integrity, 10(4), 335-344.

Petter, J. (2005). Responsible behavior in bureaucrats: an expanded conceptual framework, Public Integrity, 7(3), 197-217.

Pettit, P. (2007). Responsibility incorporated, Ethics, 117(2), 171-201.

Quiggin, J. (2010). Zombie economics: how dead ideas still walk among us. Princeton: Princeton University Press.

Rich, W. (1996). The moral choices of garbage collectors: administrative ethics from below, American Review of Public Administration, 26(2), 201-212.

Scanlon, T M. (1998). What we owe to each other. Cambridge MA: Harvard University Press.

Schedler, A. (1998). The normative force of electoral promises. Journal of Theoretical Politics, 10 (2), 191-214.

Walter, E. B. (2010). Plans and Prospects for Financial Regulatory Reform, Speech by SEC Commissioner, UC San Diego, April 23). Retrieved from http://www.sec.gov/news/speech/2010/spch042310ebw.htm 
Shenon, P. (2008). The Commission: an uncensored history of the 9/11 investigation. New York: Hatchette Book Group.

Smiley, M. (1992). Moral responsibility and the boundaries of community: power and accountability from a pragmatic point of view. Chicago: University of Chicago Press.

Smiley, M. (2011). Collective responsibility. In Zalta, E. N. (Ed.) The Stanford Encyclopedia of Philosophy. Retrieved from http://plato.stanford.edu/archives/spr2011/entries/collective-responsibility/.

Sorabji, R. (1980). Necessity, cause and blame: perspectives on Aristotle's theory. Ithaca: Cornell University Press.

Sorkin, A. R. (2009). Too big to fail: the inside story of how WallSstreet and Washington fought to save the financial system - and themselves. New York: Viking.

Standard and Poor's. (2008, February 7). S\&P's steps to further manage potential conflicts of interest, strengthen the ratings process, and better serve the markets. Retrieved from http://media.corporateir.net/media files/irol/96/96562/sp leadership.pdf \{editor?\}

Steiker, C. S., \& Steiker, J. M. (1995). Sober second thoughts: reflections on two decades of constitutional regulation of capital punishment, Harvard Law Review, 109(2), 355-438.

Sullivan, H. (2003). New forms of local accountability: coming to terms with 'many hands'?, Policy \& Politics, 31(3), 353-369.

Thompson, D. (1980). The moral responsibility of public officials: the problem of many hands, American Political Science Review, 74(4), 905-916.

Thompson, D. (1987). Political ethics and public office. Cambridge, MA: Harvard University Press.

Thompson, D. (2005). Restoring responsibility: ethics in government, business and healthcare. Cambridge: Cambridge University Press.

Tong, R. (1985). Ethics in policy analysis. Upper Saddle River NJ: Prentice-Hall. 
U.S. Congress. (2010, January 5). Dodd-Frank Wall Street Reform and Consumer Protection Act, H. R. 4173, Title IX, subtitle C. 11th Cong., 2nd sess. Retrieved fromhttp://thomas.loc.gov/cgi-bin/query/z?c111:H.R.4173: \{Editor: colon is necessary\}

U.S. Department of Defense. (2003). News Briefing - Secretary Rumsfeld and Gen. Myers, April 11, 2003. Retrieved from http://www.defense.gov/transcripts/transcript.aspx?transcriptid=2367

U.S. Secretary of the Interior. (2010, May 19) Establishment of the Bureau of Ocean Energy Management, the Bureau of Safety and Environmental Enforcement, and the Office of Natural Resources Revenue. Retrieved from http://elips.doi.gov/app_so/act_getfiles.cfm?order_number=3299

U.S. Securities and Exchange Commission. (2011). Credit rating agencies, Retrieved from http://www.sec.gov/spotlight/dodd-frank/creditratingagencies.shtml

U.S. Senate. (2010, April 23). Permanent Subcommittee on Investigations, Committee on Homeland Security and Governmental Affair, Hearings on Wall street and the financial crisis: the role of credit rating agencies, Exhibit List. Retrieved from http://hsgac.senate.gov/public/_files/Financial_Crisis/042310Exhibits.pdf

Urbina, I. (2010, June 5). In Gulf, it was unclear who was in charge of rig, New York Times. Retrieved from http://www.nytimes.com/2010/06/06/us/06rig.html?scp=1\&sq=\%22who\%20was\%20in\%20charge\%20of\%20rig $\% 22 \& s t=c s e$

Van de Poel, I. (2008). How should we do nanoethics? A network approach for discerning ethical issues in nanotechnology, NanoEthics, 2(1), 25-38.

Van de Poel, I., \& Zwart, S. D. (2010). Reflective equilibrium in R \& D networks, Science, Technology, \& Human Values, 35(2), 174-99.

Van der Heijden, J. (2010). On peanuts and monkeys: private sector involvement in Australian building control, Urban Policy and Research, 28(2), 195-210.

Van Gorp, A. (2005). Ethical issues in engineering ethics: safety and sustainability. Delft, Netherlands: Delft University of Technology and Eindhoven University of Technology. 
Wachs, M. (1990). Ethics and advocacy in forecasting for public policy. Business \& Professional Ethics Journal, 9 $(1 / 2), 141-157$.

Walzer, M. (1973). Political action: the problem of dirty hands, Philosophy \& Public Affairs, 2(2), 160-180.

Wempe, J.F.D.B. (1998). Market and morality: business ethics and the dirty and many hands dilemma. Amsterdam: Eburon.

West, E. (2000). Organisational sources of safety and danger: sociological contributions to the study of adverse events, Quality in Health Care, 9(2), 120-126.

White House Press Office (2010). President Obama announces members of the BP Deepwater Horizon Oil Spill and Offshore Drilling Commission. Retrieved from http://www.whitehouse.gov/the-press-office/president-obamaannounces-members-bp-deepwater-horizon-oil-spill-and-offshore-drill

Zwart, S. D., Van de Poel, I., Van Mil, H., \& Brumsen, M. (2006). A network approach for distinguishing ethical issues in research and development, Science and Engineering Ethics, 12(4), 663-684.

\section{Notes}

*An earlier shorter version of this chapter appeared in the American Review of Public Administration [vol. and number to come] 2014.

${ }^{1}$ The responsibility-denying phrase comes from Secretary of Defense Donald Rumsfeld, defending the military response to looting and disorder in Baghdad after the U.S. invasion: "Think what's happened in our cities when we've had riots, and problems, and looting. Stuff happens!” (U.S. Department of Defense, 2003).

${ }^{2}$ The problem was first analyzed in this way in Thompson (1980, revised, 1987, reprinted 2005). The phrase alludes to the metaphor of "dirty hands" (Walzer, 1973). The "many hands" articles have generated a large literature that continues to grow. The most extended discussions are by Bovens (2010, 2007, 2005, 1998), who carries the analysis 
further and proposes responses to the problem that are consistent with Thompson; and Smiley (1992), who criticizes Thompson's conceptual criteria for responsibility. A formal analysis of the problem is given by Mastop (2010). The Thompson formulation of the problem has proved relevant in a wide range of subjects and disciplines: blame attribution (McGraw, 1991,1990); city planning forecasting (Wachs, 1990); computing accountability (Nissenbaum, 1996); corporate management (Wempe, 1998; Kaptein, 1998); crisis management (Boin, et al. 2010); engineering (Doorn and Fahlquist 2010; Doorn, 2012; van Gorp, 2005; Cohen and Grace, 1994); criminal justice (Steiker and Steiker, 2005; DiIulio, 1988); European law (Bovens, 2007); financial analysis (Hildreth 1983); garbage collection ethics (Rich, 1991); government regulation (Black, 2008); healthcare (West, 2000; Leichter, 1992), European local government (Denton and Flinders, 2006; Sullivan, 2003; Becquart-Leclercq, 1982); law of war (Bluhm and Heineman, 2007, 313-15, 218); nanoethics (van de Poel, 2008); political campaigning (Schedler 1998); professional ethics (DeMartino 2011, 133-34); public administration (van der Heijden, 2010; Pesch, 2008; Petter 2005; Christensen and Laegreid, 2002; Dobel, 1990; Burke, 1986; and Tong, 1985, 67-73); organization theory (Dubnick, 2003; Jos, 1988); research and development networks (van de Poel and Zwart, 2010); resignation in protest (Mulgan, 2002; Dobel, 1999); school governance (Allen and Mintrom, 2010); and technology assessment (Zwart et al., 2006)..

3. "With regular incantations of 'I accept full responsibility,' an official strengthens his or her own political standing - by reassuring the public that someone is in charge and by projecting an image of a courageous leader who does not pass the buck.... the ritual often quells public debate about a controversial decision or policy, effectively blocking further inquiry into the genuine moral responsibility of all of the officials involved..." (Thompson, 1980, 907).

${ }^{4}$ An important exception is Miller (2006) who has developed a cogent individualist account of collective responsibility.

5. For a discussion of how under certain conditions collectivities can be blamed even if they are not properly regarded as human agents: see Scanlon, 2008, pp. 160-66.

${ }^{6}$ Unlike many proponents of collective agency, Pettit (2007) explicitly insists that his account is consistent with individual responsibility: "The regime I envisage would hold individual enactors responsible for any harm that they might have refused to do and didn't' (p. 197). 
${ }^{7}$ In addition to Bovens $(2010 ; 2007 ; 1998)$ and Thompson $(2005 ; 1987 ; 1980)$, see Luban et al. (1992).

${ }^{8}$ These criteria raise notoriously difficult philosophical issues, only a few of which are mentioned here. In addition to the contemporary works cited in the notes that follow, see the classic source, which is still the most suggestive: Aristotle 1993, Bk. III. 1-5. Also see Sorabji (1980).

${ }^{9}$ The interpretation of the criterion is not only more complex than can be indicated here, but it is also a chief point of controversy between two of the best works in the theory of responsibility. (cf. Hart \& Honoré, 1959, pp. 61-62, pp. 116-17, pp. 103-22; Feinberg, 1970, p. 184, pp. 201-07). The interpretation here more closely follows Feinberg.

${ }^{10}$ Notice that the cause can take various forms, such as being a necessary element in some set of conditions generally connected with the harm, operating as someone's reason for doing something harmful, constituting an opportunity for doing the harm or denying a safeguard against the harm (Hart \& Honoré, 1959, p. 122).

${ }^{11}$ A political theorist has many excuses, some of which might even be valid, for disregarding the relevant but complex metaphysical problems raised by this criterion. For a sample of the problems and various approaches to addressing them, see Pereboom (2009); and Kane (2002).

${ }^{12}$ A notable exception to the Commission's tendency to avoid assigning individual blame is its pointed criticism of CIA Director George Tenet for failing to undertake the organizational reform that arguably could have avoided some of the mistakes that led to the disaster discussion (National Commission on Terrorist Attacks, 2004, 358).

${ }^{13}$ The book that identifies the most hands is appropriately titled: All the Devils are Here (McLean \& Nocera, 2010). As one reviewer wrote: "Some of us want to tie the financial crisis to Wall Street and Washington. Others want to blame greedy and ill-informed consumers, rouge traders and brokers, out-of-control lenders and people with a Pollyanna view of the world. McLean and Nocera make a convincing argument that it's all of the above. And more" (McNay, 2010). Other useful discussions of the crisis include Johnson \& Kwak (2011); Quiggin (2010); and Sorkin (2009).

${ }^{14}$ For an insider's view, see Jerome S. Fons, Former Managing Director of Credit Policy, Moody's Investor Services, Testimony to Congress, U.S. House of Representatives, Committee on Oversight and Government Reform, Hearing: Credit Rating Agencies and the Financial Crisis, October 23 2008, quoted in Office of Special Inspector General (2009, p. 136). 